\title{
Chemical and mineralogical characterization of waste generated in the petroleum industry and its correlation with ${ }^{226} \mathrm{Ra}$ and ${ }^{228} \mathrm{Ra}$ contents
}

\author{
M.H.P. Gazineu ${ }^{1,2}$, C.A. Hazin ${ }^{2}$ and J .M.O. Godoy ${ }^{3}$ \\ ${ }^{1}$ Universidade Católica de Pernambuco, Departamento de Química, Rua do Príncipe 596, \\ 50050-900 Recife, Brasil, e-mail: helena@truenet.com.br \\ ${ }^{2}$ Universidade Federal de Pernambuco, Departamento de Energia Nuclear, Av. Prof. Luiz \\ Freire 1000, 50740-540 Recife, Brasil \\ ${ }^{3}$ Instituto de Radioproteção e Dosimetria, Comissão Nacional de Energia Nuclear, Caixa \\ Postal 37750, Barra da Tijuca, 22643-970 Rio de Janeiro, RJ, Brasil
}

\begin{abstract}
Scales and sludge are commonly formed during oil and gas extracting and processing operations. They usually appear when injection and formation water with different chemical characteristics come into contact. When the produced water is brought to the surface alongside with the oil, a precipitate can be deposited on the walls of pipes and equipment, forming the so-called scales. Otherwise they can accumulate in the form of sludge on the bottom of storage tanks, separators, and other equipment. Radium is the main radionuclide brought to the surface with oil and produced water and it co-precipitates with barium forming complex compounds of sulfates, carbonates and silicates. These compounds are the main constituents of scale and sludge. The objective of this work was to relate the radium content of scales and sludge to their chemical and mineralogical composition. Samples were taken from a PETROBRAS Unit in the State of Sergipe, in Northeast Brazil. They were collected either from the inner surface of water pipes or from containers in the waste storage area of the Unit. Oil was separated from the solid material in a Soxhlet extractor equipment by using aguarras as solvent. The concentrations of ${ }^{226} \mathrm{Ra}$ and ${ }^{228} \mathrm{Ra}$ were determined by gamma spectrometry. Both the mineralogical and chemical composition of samples were determined by X-ray diffraction and X-ray fluorescence, respectively, and used to characterize samples as scales or sludge. The results showed that scales are mainly formed by $\mathrm{BaSO}_{4}$ and $\mathrm{CaCO}_{3}$ while sludge composition is quite variable, having higher contents of $\mathrm{SiO}_{2}$ and $\mathrm{FeO}_{3}$ than those observed on scale samples. The measured activity concentrations of ${ }^{226} \mathrm{Ra}$ and ${ }^{228} \mathrm{Ra}$ are strongly correlated for both kinds of samples.
\end{abstract}

\section{INTRODUCTION}

There are several human activities that lead to the production of Naturally Occurring Radioactive Material (NORM). At the same time several types of industrial activities tend to concentrate NORM in their byproducts, forming the Technologically Enhanced Naturally Occurring Radioactive Material (TENORM). Examples of such activities include mining, milling and processing of uranium ores and mineral sands, phosphate manufacture, burning of fossil fuels, metal refining and some others, including petroleum extraction and processing activities [1, 2].

During oil and gas processing, water is pumped to the surface alongside with the oil. Physical and chemical changes occur when the water is brought to regions of different temperature, pressure and flow velocity. Precipitation occurs and scale and sludge accumulate in the equipment where these changes take place. 
Scales precipitate in the interior of piping, filters, injection wellhead equipment, and other water-handling equipment. Accumulation of these residues can cause considerable production losses and involves expensive cleaning procedures and frequent maintenance work. The density of scale is approximately 2.6 g.cm $\mathrm{cm}^{-3}$ [3]. It is basically formed from precipitates of barium and strontium sulfates and calcium carbonate, which form deposits in the inner surface of pipes and equipment.

Sludge, on the other hand, is a mixture of oil, sediment and finely divided corrosion products that accumulates inside piping, in the bottom of storage tanks, separators and any other equipment where produced water is handled. Sludge is formed mostly from carbonates and silicates containing radium; its density is approximately 1.6 g. $\mathrm{cm}^{-3}$ [3-6].

Both scale and sludge may be radioactive. This radioactivity is due to radium co-precipitation with barium and strontium sulfates during scale and sludge formation. The dominating radionuclides present in scales and in other precipitates are ${ }^{226} \mathrm{Ra}$ and ${ }^{228} \mathrm{Ra}$, with typical concentrations ranging from $1-1,000 \mathrm{kBq} \mathrm{kg}^{-1}$, although concentrations as high as $15,000 \mathrm{kBq} \mathrm{kg}^{-1}(410,000 \mathrm{pCi} \mathrm{g})$ have been reported in the literature [3]. Values for ${ }^{228} \mathrm{Ra}$ in scales and sludge are, in general, not much lower than for ${ }^{226} \mathrm{Ra}$. Reported radium concentrations in sludge are normally lower than in scales [7-8].

In Brazil, values of activity concentration for scales removed from an offshore oil producing facility ranged from 19.1 to $323.0 \mathrm{kBq} \mathrm{kg}^{-1}$ and 4.21 to $235 \mathrm{kBq} \mathrm{kg}^{-1}$ for ${ }^{226} \mathrm{Ra}$ and ${ }^{228} \mathrm{Ra}$, respectively. The sludge collected from the same facility presented concentrations ranging from 0.36 to $367 \mathrm{kBq} \mathrm{kg}^{-1}$ for ${ }^{226} \mathrm{Ra}$ and from 0.25 to $343 \mathrm{kBq} \mathrm{kg}^{-1}$ for ${ }^{228} \mathrm{Ra}$, respectively [6].

The radioactivity of scale and sludge formed during oil and gas production processes is an important issue, mainly from the point of view of radiation protection and has received particular attention during the last years $[1,4]$. Scales and sludge that accumulate in many oil and gas exploration and production facilities can cause exposure of maintenance and other personnel and can pose a significant radiological hazard to exposed individuals [9].

\section{MATERIAL AND METHODS}

Fifteen samples were collected from PETROBRAS oil extraction and processing units in the State of Sergipe, Northeast of Brazil. Sludge samples were collected from barrels stored in the patio of the main Unit. These barrels accumulate residues coming from the cleaning of separation and storage tanks and other equipment during maintenance operations. Scale samples, on the other hand, were taken from produced water pipelines. Two samples (9 and 10) were collected from a nearby holding pit, used in the past for the disposal of wastes generated at several PETROBRAS Units in the same oil exploration area.

The first step in the analysis process was to separate the oil and sediment phases. The separation was carried out in a Soxhlet extractor equipment by using aguarras as solvent. In this procedure, around $40 \mathrm{~g}$ of each sample were placed in a thimble capsule and introduced in the Soxhlet system together with $120 \mathrm{~mL}$ of aguarras. The system was heated to $90 \pm 5^{\circ} \mathrm{C}$ and kept at this temperature until all the oil had been extracted from the sample. Following oil extraction, samples were partially dried in the sun and then placed in an oven at $100{ }^{\circ} \mathrm{C}$ for 60 minutes in order to eliminate any solvent residue still present. Dried samples were ground to a fine powder and analyzed in an X-ray diffraction equipment (Rigaku Industrial Corporation) for determining the mineralogical phases present.

Another step involved the chemical characterization of samples by X-ray fluorescence spectrometry, which was carried out in a RIX 3000 equipment (Rigaku Industrial Corporation). Initially, the loss by fire was determined by placing the sample in a furnace and heating up to $1000{ }^{\circ} \mathrm{C}$. Samples were incinerated for 10 hours up to reaching constant weight and the carbonate plus organic matter content determined by gravimetry.

The mineralogical and chemical compositions of samples were determined by X-ray diffraction and X-ray fluorescence, respectively, and used to characterize the samples as scales or sludge.

The activity concentrations of ${ }^{226} \mathrm{Ra}$ and ${ }^{228} \mathrm{Ra}$, on the other hand, were determined by gamma spectrometry. In this procedure, $20 \mathrm{~g}$ of each sample were placed in $5 \mathrm{~cm}$ diameter-, $1 \mathrm{~cm}$ height cans, which were sealed with silicone and black electric tape in order to prevent radon gas leakage. Samples were then stored for a minimum period of three weeks so that radioactive equilibrium between ${ }^{226} \mathrm{Ra}$ 
and its short lived progeny was reached. Samples were then counted in a HP Ge detector (Canberra ${ }^{\mathrm{TM}}$ ). The energy resolution, expressed in terms of its FWHM, was $1.8 \mathrm{keV}$ at $1332 \mathrm{keV}$. The distance from the source to the detector was kept at $11 \mathrm{~cm}$ in order to reduce the dead time to acceptable values. However, samples that presented very high counting rates were counted at a $19 \mathrm{~cm}$ distance from the detector. The counting efficiency was determined for the specified geometries and energies, by using a standard solution of ${ }^{152} \mathrm{Eu}$ (Amersham).

Under conditions of secular equilibrium, the ${ }^{226} \mathrm{Ra}$ content can be determined through either the $352 \mathrm{keV}$ peak of ${ }^{214} \mathrm{~Pb}$ or the $609 \mathrm{keV}$ of ${ }^{214} \mathrm{Bi}$. In this work the $609 \mathrm{keV}$ gamma of ${ }^{214} \mathrm{Bi}$ (yield $=46.3 \%$ ) was used, in order to minimize the self-absorption effect. Radium-228, on the other hand, was determined through its direct progeny, ${ }^{228} \mathrm{Ac}$, which emits $911 \mathrm{keV}$ gamma rays with a $27.7 \%$ yield.

\section{RESULTS AND DISCUSSION}

The results of gamma measurements are shown in Table 1. As it can be seen from the data, samples 1, 6 and 11 presented the highest ${ }^{226} \mathrm{Ra}$ and ${ }^{228} \mathrm{Ra}$ activity concentrations. Samples 1 and 6 were collected from barrels used to store wastes from several PETROBRAS plants located in the area under investigation. Sample 11, on the other hand, was collected directly from the surface of a produced water pipeline (in a Station called Sítio Novo) and had the appearance of scale, being formed by several layers, which had been deposited throughout the years. Samples 3, 7 and 8 were also collected from produced water pipelines, but from a different location (Station SZ II). They had much lower radium concentrations and their appearance was somewhat different from sample 11, as the layers of deposited materials were not clearly defined. Samples collected from the holding pit had the lowest radium concentrations. In a certain way this result was expected since some amount of clay and mud present in the pond was possibly collected together with the oil and corrosion residues.

As there was no record of the origin of these and of other materials stored in the barrels, the X-ray fluorescence technique was used to determine sample chemical composition, which could help in classifying these samples as scales or sludge. Further, X-ray diffraction analyses were carried out aiming to identify the mineralogical phases present in both scales and sludge samples according to their content of barite, silicate, carbonate and other phases.

Table 1. Activity concentrations of ${ }^{226} \mathrm{Ra}$ and ${ }^{228} \mathrm{Ra}$ on scale and sludge samples.

\begin{tabular}{|c|c|c|c|}
\hline $\begin{array}{l}\text { Sample } \\
\text { number }\end{array}$ & $\begin{array}{c}\text { Sample } \\
\text { Type/Origin }\end{array}$ & $\begin{array}{c}{ }^{226} \mathrm{Ra} \\
\left(\mathrm{kBq} \mathrm{kg}^{-1}\right)\end{array}$ & $\begin{array}{c}{ }^{228} \mathrm{Ra} \\
\left(\mathrm{kBq} \mathrm{kg}^{-1}\right)\end{array}$ \\
\hline 1 & Sludge/ Barrel & 3,500 & 2,052 \\
\hline 2 & Sludge/ Barrel & 150.9 & 123.3 \\
\hline 3 & Scale/ Produced water pipeline & 129.0 & 192.4 \\
\hline 4 & Sludge/ Barrel & 167.8 & 143.6 \\
\hline 5 & Sludge/ Barrel & 122.0 & 105.5 \\
\hline 6 & Sludge/ Barrel & 2,518 & 1,624 \\
\hline 7 & Scale/ Produced water pipeline & 130.9 & 131.4 \\
\hline 8 & Scale/ Produced water pipeline & 120.8 & 139.2 \\
\hline 9 & Sludge/Holding pit & 34.9 & 35.5 \\
\hline 10 & Sludge/Holding pit & 2.4 & Not detected \\
\hline 11 & Scale/ Produced water pipeline & 955.0 & 792.0 \\
\hline 12 & Sludge/ Barrel & 118.0 & 99.2 \\
\hline 13 & Sludge/ Barrel & 110.0 & 130.0 \\
\hline 14 & Sludge/ Barrel & 50.0 & 46.0 \\
\hline 15 & Sludge/ Barrel & 127.0 & 110.0 \\
\hline
\end{tabular}


The results of both X-ray diffraction and X-ray fluorescence analyses are shown in Table 2 along with the amount of oil extracted from each sample prior to the chemical and mineralogical characterization. As it can be seen, barite is present in most of the samples while quartz is present only in samples 2, 9, 13, 14 and 15. Samples 1, 6, 12, 14 and 15 showed the presence of a mineral called rasvumite $\left(\mathrm{KFe}_{2} \mathrm{~S}_{3}\right)$. Another mineral (mercallite - $\mathrm{KHSO}_{4}$ ) was present in samples 2, 5, 7, 8, 10 and 13.

Table 2. Mineralogical and chemical composition of scale and sludge.

\begin{tabular}{|c|c|c|c|c|c|c|c|c|c|}
\hline \multirow[b]{2}{*}{$\begin{array}{l}\text { Sample } \\
\text { number }\end{array}$} & \multirow[b]{2}{*}{ Mineral } & \multirow[b]{2}{*}{ Mineral } & \multirow[b]{2}{*}{$\begin{array}{c}\text { Oil extracted } \\
(\%)\end{array}$} & \multicolumn{6}{|c|}{ Concentration (g.kg $\left.{ }^{-1}\right)$} \\
\hline & & & & BaO & $\mathrm{SiO}_{2}$ & $\mathrm{SO}_{3}$ & $\mathrm{CaO}$ & SrO & $\mathrm{Fe}_{2} \mathrm{O}_{3}$ \\
\hline 1 & $\begin{array}{c}\text { Barite } \\
\left(\mathrm{BaSO}_{4}\right)\end{array}$ & $\begin{array}{c}\text { Rasvumite } \\
\left(\mathrm{KFe}_{2} \mathrm{~S}_{3}\right)\end{array}$ & 11.2 & 286 & 58 & 184 & 15.5 & 5.3 & 112 \\
\hline 2 & $\begin{array}{l}\text { Quartz } \\
\left(\mathrm{SiO}_{2}\right)\end{array}$ & $\begin{array}{l}\text { Mercallite } \\
\left(\mathrm{KHSO}_{4}\right)\end{array}$ & 41.6 & 26 & 166 & 131 & 19.3 & 0.8 & 121 \\
\hline 3 & Barite $\left(\mathrm{BaSO}_{4}\right)$ & -- & 9.2 & 580 & 7 & 299 & 13 & 35 & 16 \\
\hline 4 & Barite $\left(\mathrm{BaSO}_{4}\right)$ & -- & 35.7 & 31 & 196 & 88 & 174 & 9 & 162 \\
\hline 5 & Mercallite $\left(\mathrm{KHSO}_{4}\right)$ & -- & 53.0 & 37 & 159 & 94 & 208 & 9 & 140 \\
\hline 6 & Barite $\left(\mathrm{BaSO}_{4}\right)$ & Rasvumite $\left(\mathrm{KFe}_{2} \mathrm{~S}_{3}\right)$ & 20.7 & 206 & 105 & 120 & 167 & 37 & 140 \\
\hline 7 & Barite $\left(\mathrm{BaSO}_{4}\right)$ & Mercallite $\left(\mathrm{KHSO}_{4}\right)$ & 4.2 & 554 & 23 & 290 & 16 & 25 & 19 \\
\hline 8 & Barite $\left(\mathrm{BaSO}_{4}\right)$ & Mercallite $\left(\mathrm{KHSO}_{4}\right)$ & 4.0 & 556 & 31 & 284 & 16 & 25 & 22 \\
\hline 9 & $\begin{array}{l}\text { Quartz } \\
\left(\mathrm{SiO}_{2}\right)\end{array}$ & $\begin{array}{c}\text { Barite } \\
\left(\mathrm{BaSO}_{4}\right)\end{array}$ & 29.1 & 168 & 172 & 169 & 67 & 12 & 239 \\
\hline 10 & $\begin{array}{l}\text { Mercallite } \\
\left(\mathrm{KHSO}_{4}\right)\end{array}$ & -- & 35.0 & 16 & 45 & 152 & 134 & 8 & 361 \\
\hline 11 & $\begin{array}{c}\text { Barite } \\
\left(\mathrm{BaSO}_{4}\right)\end{array}$ & -- & 0 & 122 & 15 & 338 & 138 & 42 & 220 \\
\hline 12 & $\begin{array}{c}\text { Rasvumite } \\
\left(\mathrm{KFe}_{2} \mathrm{~S}_{3}\right)\end{array}$ & $\begin{array}{c}\text { Barite } \\
\left(\mathrm{BaSO}_{4}\right)\end{array}$ & 13.7 & 199 & 90 & 145 & 229 & 17 & 116 \\
\hline 13 & Mercallite $\left(\mathrm{KHSO}_{4}\right)$ & $\begin{array}{l}\text { Quartz } \\
\left(\mathrm{SiO}_{2}\right)\end{array}$ & 13,0 & 402 & 127 & 204 & 46 & 28 & 91 \\
\hline 14 & $\begin{array}{l}\text { Quartz } \\
\left(\mathrm{SiO}_{2}\right)\end{array}$ & $\begin{array}{l}\text { Rasvumite } \\
\left(\mathrm{KFe}_{2} \mathrm{~S}_{3}\right)\end{array}$ & 32.1 & 23 & 122 & 88 & 252 & 09 & 150 \\
\hline 15 & $\begin{array}{l}\text { Quartz } \\
\left(\mathrm{SiO}_{2}\right)\end{array}$ & $\begin{array}{l}\text { Rasvumite } \\
\left(\mathrm{KFe}_{2} \mathrm{~S}_{3}\right)\end{array}$ & 40.7 & 30 & 167 & 104 & 210 & 10 & 142 \\
\hline
\end{tabular}

Based on the results obtained from both techniques, a classification of samples as scale and sludge was made. Samples 3, 7, 8 and 11 were first classified as scales, as they were collected from the pipelines. The other samples were taken either from barrels or from the holding pit so they were initially classified as sludge. The parameters used for the final classification were oil content (scales should not have as much oil as sludge samples), radium activity concentration, mineralogical and chemical composition. Radium concentration is usually higher for scales than for sludge. Meanwhile, the mineralogical composition of scales has to show barite as the main component, while sludge samples should be high on minerals containing silicates and carbonates.

Higher concentrations of barium, strontium and sulfates indicate that the sample should be classified as scales while the presence of silicates and calcium oxide indicate that the samples are of the sludge type. Table 3 shows the classification done according to these considerations. 
Table 3. Description and location of scale and sludge samples (The classification was based on visual appearance, chemical and mineralogical composition, and radium content).

\begin{tabular}{|c|c|c|c|c|c|}
\hline $\begin{array}{l}\text { Sample } \\
\text { number }\end{array}$ & Origin & $\begin{array}{c}\text { Sample type } \\
\text { (based on appearance) }\end{array}$ & $\begin{array}{l}\text { Chemical } \\
\text { composition }\end{array}$ & $\begin{array}{l}\text { Mineralogical } \\
\text { composition }\end{array}$ & $\begin{array}{c}\text { Sample } \\
\text { Classification }\end{array}$ \\
\hline 1 & Barrel & Sludge & Scale & Scale & Scale \\
\hline 2 & Barrel & Sludge & Sludge & Sludge & Sludge \\
\hline 3 & Produced water pipeline & Scale & Scale & Scale & Scale \\
\hline 4 & Barrel & Sludge & Sludge & Scale & Sludge \\
\hline 5 & Barrel & Sludge & Sludge & Sludge & Sludge \\
\hline 6 & Barrel & Sludge & Scale & Scale & Scale \\
\hline 7 & Produced water pipeline & Scale & Scale & Scale & Scale \\
\hline 8 & Produced water pipeline & Scale & Scale & Scale & Scale \\
\hline 9 & Holding pit & Sludge & Scale/Sludge & Sludge & Sludge \\
\hline 10 & Holding pit & Sludge & Sludge & Sludge & Sludge \\
\hline 11 & Produced water pipeline & Scale & Scale & Scale & Scale \\
\hline 12 & Barrel & Sludge & Scale & Sludge & Sludge \\
\hline 13 & Barrel & Sludge & Scale & Sludge & Sludge \\
\hline 14 & Barrel & Sludge & Sludge & Sludge & Sludge \\
\hline 15 & Barrel & Sludge & Sludge & Sludge & Sludge \\
\hline
\end{tabular}

Figures 1 and 2 show the average concentration values (in mass percentage) for samples classified as scale and sludge, respectively. The bar labeled "weight loss" comprehends the amount of carbonates and organic matter determined by calcination . As it can be seen in the Figures, the average weight loss for sludge samples was higher than for scale samples, which was used as an additional factor for the classification of samples.

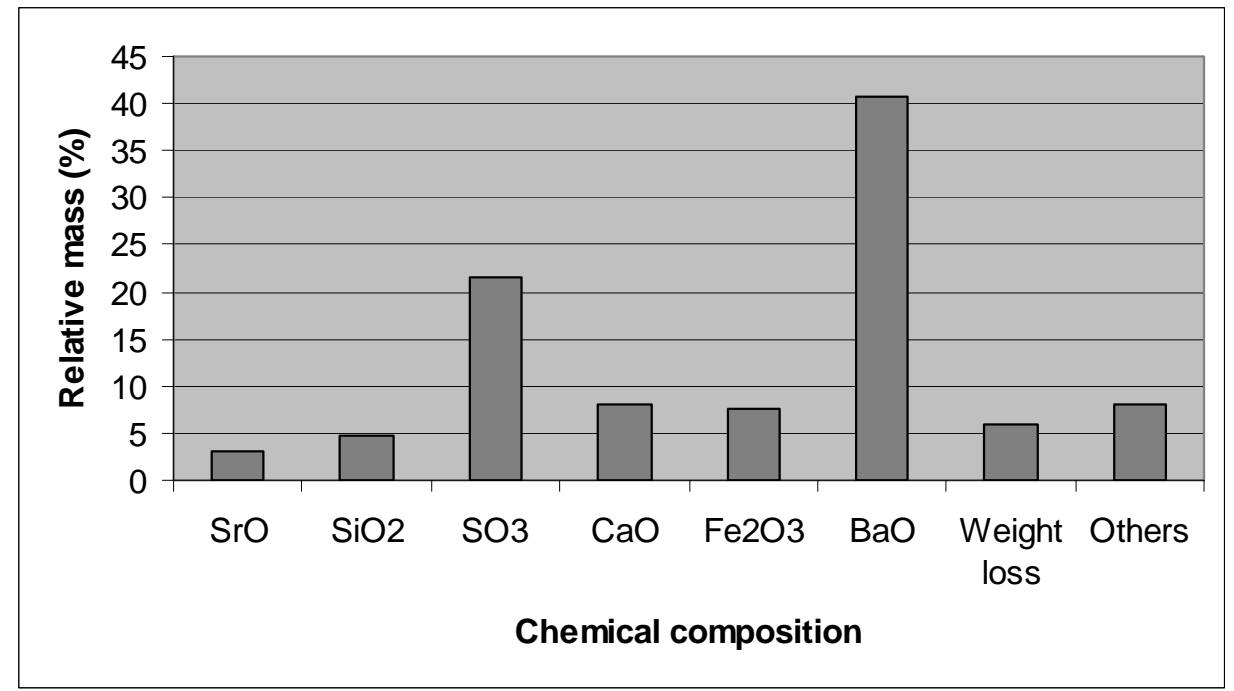

Figure 1. Average chemical composition of scale samples. 


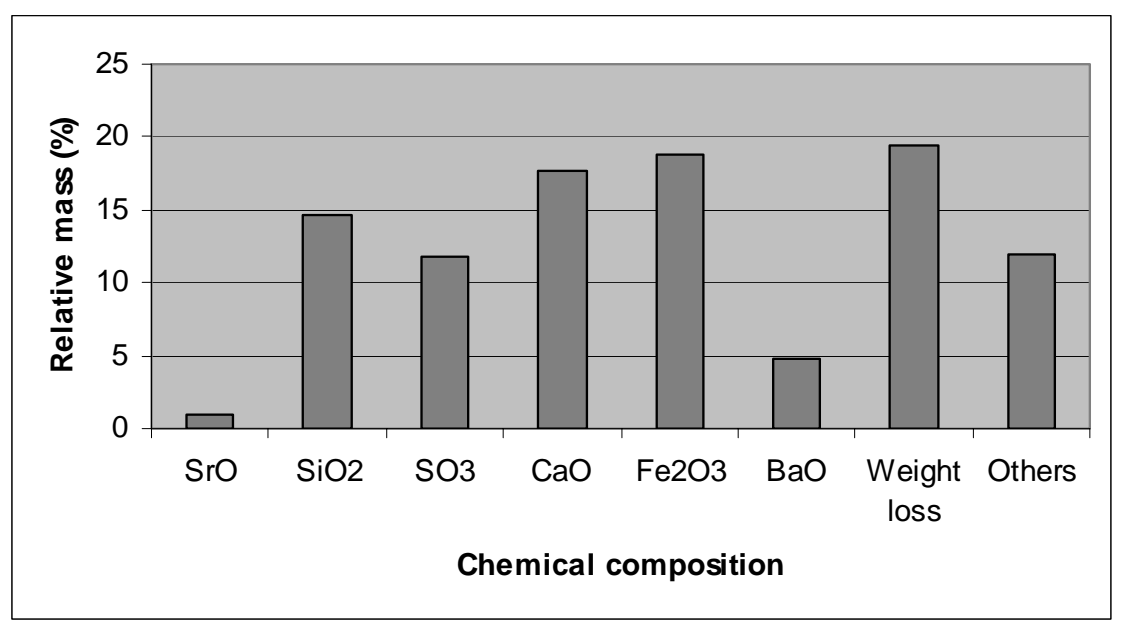

Figure 2. Average chemical composition of sludge samples.

\section{CONCLUSIONS}

The radioactive content of the analyzed material showed a wide variation for both scale and sludge samples. In the great majority of the samples the ${ }^{226} \mathrm{Ra}$ activity concentration was higher than the ${ }^{228} \mathrm{Ra}$ activity concentration. Activity concentrations as high as $3,500 \mathrm{kBq} \mathrm{kg}^{-1}$ were determined for samples collected from the storage area. It was not possible, however, to trace the origin of these residues up to the oil well or pumping station. Further work is being carried out to determine which wells bring the most radioactive residues to the surface.

As it was already found in previous studies, barium sulfate (barite) and strontium sulfate were the main constituents found in scales, while carbonates are present, together with silicates and other compounds in sludge samples.

\section{Acknowledgements}

The authors are grateful to FINEP/CTPETRO for their financial support to this project.

\section{References}

[1] Aksoy A., Al-Jarallah M. and Al-Haddad M.N., J. Environ. Radioactiv. 61 (2002) 33-40.

[2] National Research Council, Evaluation of guidelines for exposures to technologically enhanced naturally occurring radioactive materials (National Academy Press, Washington, DC, 1999).

[3] USEPA, Draft diffuse NORM-waste characterization and preliminary risk assessment (U. S. Environmental Protection Agency, Office of Radiation and Indoor Air, Washington, DC, 1993).

[4] Testa C., Desideri D., Meli M.A., Roselli C., Bassignani A., Colombo G., and Fantoni, R.F., Health Phys. 67 (1994) 34-38.

[5] Veil J.A., “Update on Cavern Disposal of NORM-Contaminated Oil Field Wastes”, Ground Water Protection Council 98 Annual Forum, Sacramento, California, Sept. 19-23, 1998 (Sacramento, CA, 1998).

[6] Godoy J.M., Cruz R.P., J. Environ. Radioactiv. 70 (2003) 199-206.

[7] Paschoa A.S., Appl. Radiat. Isotopes 49 (1998) 189-196.

[8] Vandenhove H., International Congress Series 1225 (2002) 307-315.

[9] Hamlat M.S., Djeffal S., and Kadi H., Appl. Radiat. Isotopes 55 (2001) 141-146. 